(C) 2014

Яремич Н. В., молодший науковий співробітник

Черкаська дослідна станція біоресурсів ІРГТ НААН

\title{
ВПЛИВ ВІКУ САМОК НОРОК РІЗНИХ ГЕНОТИПІВ СКАНДИНАВСЬКОЇ СЕЛЕКЦІЇ НА ПОКАЗНИКИ ПЛОДЮЧОСТІ
}

\author{
Рецензент - кандидат сільськогосподарських наук О. М. Гаврии
}

\begin{abstract}
Проведено дослідження показників плодючості самок норок різних генотипів скандинавської селекції в залежності від тривалості їх використання для розмноження в господарстві. Встановлено, щуо незалежно від кольорового типу у самок із віком зростають показники відтворювальної здатності. Так, у норок генотипів Pearl ma Scanblack максимальні значення показника багатоплідності зареєстровані $у$ самок третього року використання - 6,25-6,42 щенят $(P>0,99 \ldots 0,999)$. У звірів muny Scanglow максимальне значення даного показника спостерігалось у дворічних самок (5,48 гол.). Встановлено високовірогідний позитивний кореляційний зв'язок між показниками кількості народжених усього та народжених живими норченят $(r=0,36-0,39, p<0,001)$.
\end{abstract}

Ключові слова: норка, генотип, кольоровий mun, Scanglow, Scanblack, Pearl, плодючість, відтворювальна здатність.

Постановка проблеми. На сьогоднішній день у звірогосподарствах України збільшується частка звірів, завезених зі скандинавських країн, проте в літературних джерелах майже відсутня інформація щодо особливостей перебігу репродуктивної функції та рівня їх плодючості в умовах вітчизняних господарств. Це, в свою чергу, зумовлює актуальність розроблення оптимізованої вікової структури стада з урахуванням впливу віку самок, які використовуються для розмноження.

Аналіз основних досліджень і публікацій, у яких започатковано розв'язання проблеми. Питання раціональної вікової структури самок норок племінного ядра є важливим як у ветеринарно-зоотехнічному, так і в економічному значенні, поскільки правильна організація стада дає змогу знизити собівартість хутрової продукції й водночас підвищити іiі рентабельність. Термін племінного використання у норок найкоротший порівняно з іншими м'ясоїдними хутровими тваринами. 3 чотирьох років уже спостерігається погіршення репродуктивної здатності самок, крім того вони приносять менш життєздатне потомство [2-4]. Практикою доведено, що пік репродуктивної здатності у норок спостерігається (за умов гарної годівлі й утримання) у віці 1-2 роки $[5,6]$. Дослідження М. Д. Абрамова доводять, що середня кількість щенят у гнізді збільшується від першого року до другого, а з часом поступово знижується; аналогічна картина спостерігається й стосовно запліднення самок [1].

Метою досліджень $є$ вивчення відтворювальної здатності самок норок генотипів Scanglow, Scanblack та Pearl piзного терміну використання та можливості збільшення частки 2-3-річних самок у процесі формування племінного ядра в умовах вітчизняних звірогосподарств.

Завдання досліджень - провести порівняльне вивчення впливу віку на рівень плодючості самок норок різних генотипів скандинавської селекції.

Матеріал і методика проведення досліджень. Дослідження проводилося на базі ТОВ «Золотоніське звірогосподарство» Золотоніського району Черкаської області. Самки кожного 3 кольорових типів Scanglow, Scanblack та Pearl були поділені на три групи. Першу групу склали самки віком до року, другу - 2-річні й третю 3-річні (по n=100 гол. у кожній групі). Під час досліду були проаналізовані фактичні показники плодючості самок (кількість живих та народжених мертвими норченят) на основі звітної документації по господарству (форма звітності 6-3В та журнали з бонітування).

Результати досліджень. Дослідження показали, що самки різного терміну використання мали неоднакові показники плодючості й різні значення кількісних та якісних показників гнізд (табл. 1). Так, максимальне значення показника плідності зареєстровано у самок генотипу Scanblack третього року використання - 6,42 щенят, мінімальним - у самок цього ж кольорового типу першого року використання - 3,67 щенят $(\mathrm{P}>0,999)$. У норок Scanglow також відмічено тенденцію до зростання кількості народжених норченят із віком тварин. Так, у самок другого року використання показник плодючості на 0,76 гол. вищий порівняно 3 самками першого року використання й на 0,30 гол. вище, ніж у 


\section{СІЛЬСЬКЕ ГОСПОДАРСТВО. ТВАРИННИЦТВО}

самок третього року використання $(\mathrm{P}>0,95)$. У норок генотипу Pearl не відмічено вірогідної різниці за досліджуваним показником у одно- та дворічних самок $(\mathrm{P}<0,95)$. Плідність самок третього року використання виявилася на 0,45-0,47 голів вищою порівняно 3 рештою самок цього типу.

Аналогічна тенденція відмічалась і за показником кількості отриманих живих норченят на самку, яка брала участь у розмноженні. Максимальним даний показник був по всіх групах у трирічних самок (5,19-6,19 голів), а мінімальний - у самок, які використовуються для розмноження вперше (3,48-5,61 голів).

Дещо іншу характеристику процесу відтворення норок спостерігали за показником кількості народжених мертвих норченят, кількість яких по гніздах становила від 1-ї до 8-ми голів. У середньому в розрахунку на штатну самку по групі самок Scanglow цей показник склав 0,10-0,61 голів. Так, норки першого року використання мали мінімальне значення за цим показником 0,23 голів, а трирічні самки мали в гніздах у середньому по 0,61 голови мертвонароджених норченят $(\mathrm{P}>0,95)$.

Для короткошерстих норок чорного типу забарвлення Scanblack максимальна кількість мертвонароджених щенят зареєстрована у самок другого року (0,59 голів). Для норок Pearl характерною була зворотна тенденція, тобто, зі зростанням тривалості використання тварин у господарстві показник кількості мертвонароджених норченят знижувався: 3 0,43 голів (для молодих самок) до 0,10 голів (для самок третього року використання).

3 метою встановлення залежності між плідністю самок і тривалістю використання їх для розмноження був проведений кореляційний аналіз (табл. 2).

Високовірогідним для норок типу Scanblack був зв'язок між показниками кількості всього народжених норченят i народжених живими; відповідні коефіцієнти становили 0,36 та 0,39 ( $\mathrm{P}>0,999)$, тобто зі збільшенням віку самки показники відтворення мали тенденцію до зростання. Для решти груп самок встановлені коефіцієнти були невірогідні $(\mathrm{P}<0,95)$. Встановлені закономірності між показником тривалості використання тварин у господарстві й кількістю мертвонароджених норченят.

Для норок коричневого Scanglow та чорного Scanblack типів забарвлення кореляційна залежність мала пряму залежність ( $\mathrm{r}=0,09$ та 0,41), проте лише для самок Scanglow виявилася вірогідною (P>0,999). Для самок Pearl кореляція також виявилася високовірогідною, хоча мала обернений зв'язок $(\mathrm{r}=-0,22, \mathrm{P}>0,999)$.

Результати дисперсійного аналізу також свідчать про наявність впливу віку самки на показники відтворювальної здатності.

Для показника плодючості самок частка впливу віку становила 1-15\%. Вірогідний вплив тривалості використання самок у звірогосподарстві для розмноження виявився лише на показник кількості мертвонароджених норченят у норок Scanblack та Pearl, однак частка впливу даного фактора виявилася невисокою - лише 2-7\% $(\mathrm{P}>0,95)$.

\section{1. Відтворювальна здатність самок норок різного терміну використання в господарстві}

\begin{tabular}{|c|c|c|c|c|c|c|c|c|}
\hline \multirow{3}{*}{$\begin{array}{l}\text { Тип } \\
\text { норок }\end{array}$} & \multirow{3}{*}{$\begin{array}{c}\text { Вік самок, } \\
\text { роки }\end{array}$} & \multirow{3}{*}{$\mathrm{N}$} & \multicolumn{6}{|c|}{ Одержано молодняку на самку, яка брала участь у розмноженні, голів } \\
\hline & & & \multicolumn{2}{|c|}{ усього } & \multicolumn{2}{|c|}{ живих } & \multicolumn{2}{|c|}{ мертвих } \\
\hline & & & $\mathrm{M} \pm \mathrm{m}$ & $\sigma$ & $\mathrm{M} \pm \mathrm{m}$ & $\sigma$ & $\mathrm{M} \pm \mathrm{m}$ & $\sigma$ \\
\hline \multirow{3}{*}{ 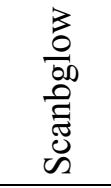 } & 1 & 99 & $4,72 \pm 0,29$ & 2,91 & $4,49 \pm 0,30$ & 2,93 & $0,23 \pm 0,08$ & 0,75 \\
\hline & 2 & 100 & $5,48 \pm 0,29$ & 2,99 & $5,08 \pm 0,28$ & 2,78 & $0,36 \pm 0,10$ & 0,97 \\
\hline & 3 & 100 & $5,18 \pm 0,25$ & 2,50 & $5,19 \pm 0,23$ & 2,40 & $0,61 \pm 0,20 *$ & 1,40 \\
\hline \multirow{3}{*}{ 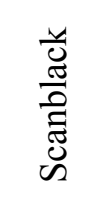 } & 1 & 99 & $3,67 \pm 0,30$ & 3,00 & $3,48 \pm 0,29$ & 2,92 & $0,22 \pm 0,08$ & 0,77 \\
\hline & 2 & 98 & $5,03 \pm 0,31$ & 3,05 & $4,41 \pm 0,28$ & 2,80 & $0,59 \pm 0,13$ & 1,28 \\
\hline & 3 & 100 & $6,42 \pm 0,18^{* *}$ & 1,83 & $5,95 \pm 0,20 * *$ & 1,98 & $0,41 \pm 0,11$ & 1,08 \\
\hline \multirow{3}{*}{ 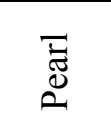 } & 1 & 99 & $5,78 \pm 0,24$ & 2,40 & $5,61 \pm 0,25$ & 2,40 & $0,43 \pm 0,08$ & 0,78 \\
\hline & 2 & 100 & $5,80 \pm 0,27$ & 2,71 & $5,63 \pm 0,27$ & 2,71 & $0,16 \pm 0,06$ & 0,58 \\
\hline & 3 & 100 & $6,25 \pm 0,22 *$ & 2,18 & $6,19 \pm 0,22$ & 2,18 & $0,10 \pm 0,02$ & 0,23 \\
\hline
\end{tabular}

Примітка: * - $\mathrm{P}>0,95 ; * *$ - $\mathrm{P}>0,999$ 
СІЛЬСЬКЕ ГОСПОДАРСТВО. ТВАРИННИЦТВО

2. Кореляційна залежність між показниками відтворювальної здатності й віком самок норок різних генотипів

\begin{tabular}{|c|c|c|c|c|c|c|}
\hline \multirow{2}{*}{ Тип норок } & \multicolumn{6}{|c|}{ Одержано молодняку на штатну самку, голів } \\
\cline { 2 - 7 } & \multicolumn{2}{|c|}{ усього } & \multicolumn{2}{c|}{ живих } & \multicolumn{2}{c|}{ мертвих } \\
\cline { 2 - 7 } & $\mathrm{r}$ & $\mathrm{tr}$ & $\mathrm{r}$ & $\mathrm{tr}$ & $\mathrm{r}$ & $\mathrm{tr}$ \\
\hline Scanglow & 0,09 & 1,36 & 0,08 & 1,19 & $0,41^{* * *}$ & 6,73 \\
\hline Scanblack & $0,39 * * *$ & 7,28 & $0,36 * * *$ & 6,69 & 0,09 & 1,61 \\
\hline Pearl & 0,04 & 0,72 & 0,09 & 1,64 & $-0,22^{* * *}$ & 3,96 \\
\hline
\end{tabular}

Примітка: *** - $\mathrm{P}>0,999$

\section{Висновки:}

1. У ході проведених досліджень встановлено, що достовірно вищі показниками плодючості у норок генотипів Pearl та Scanblack спостерігались у самок третього року використання - 6,25$6,42$ щенят ( $>>0,95 \ldots 0,999)$. У звірів типу Scanglow максимальний показник багатоплідності зареєстровано у дворічних самок - 5,48 гол., у трирічних тварин даний показник був нижчим

\section{БІБЛІОГРАФІЯ}

1. Абрамов М. Д. Норководство / М. Д. Абрамов. - М. : Колос, 1974. -208 с.

2. Афанасьев В. А. Клеточное пушное звероводство / В. А. Афанасьев, Н. Ш. Перельдик. М. : Колос, 1996. - $400 \mathrm{c}$.

3. Мирось В. В. Довідник кролівника та звіровода / В. В. Мирось, К. В. Калмиків, О. Г. Зайцев. - К. : Урожай, 1990. - 265 с.

4. Сахаров $C$. В. К вопросу о рациональной на 5,5 \%. Встановлено високовірогідний позитивний кореляційний зв'язок між показниками кількості всього народжених норченят і народжених живими ( $\mathrm{r}=0,36$ та $\mathrm{r}=0,39),(\mathrm{P}>0,999)$.

2. Отримані результати досліджень свідчать: незалежно від генотипу у самок із віком зростають показники відтворювальної здатності, що вказує на можливість збільшення частки 2-3річних самок у стаді.

структуре на норковых фермах / С. В. Сахаров // Советы звероводу: сборник по обмену опытом. М. : Экономика, 1967. - № 1. - С. 80-83.

5. Bouman J. De invloed vande leeftijd van hersten op produktie / J. Bouman // Pelsdierenfokker. - 1977. - № 11. - P. 160-163.

6. Tauson A. Hvilken betydning hor taevens alder for avlsresultatet / A. Tauson // Dansk Pels-dyran. 1976. - № 9. - P. 349-350. 